\title{
Effect of Business Risk, Company Size, and Asset Structure on Capital Structure with Profitability as an Intervening Variable (Case Study on Manufacturing Companies on the Indonesia Stock Exchange)
}

\author{
Robby Rahadi Putra ${ }^{1}$, Maya Sari ${ }^{2}$, Widia Astuty ${ }^{3}$ \\ ${ }^{1,2,3}$ Universitas Muhammadiyah Sumatera Utara, Indonesia \\ Corresponding Author: Robby Rahadi Putra
}

\begin{abstract}
The purpose of this study was to determine and analyze the effect of business risk, company size, and asset structure on capital structure with profitability as an intervening variable (case study on Manufacturing Companies on the Indonesia Stock Exchange). The populations in this study are all Manufacturing Companies listed on the Indonesia Stock Exchange for the 2015-2019 period. Based on the purposive sampling method, 71 companies were obtained as samples. The data analysis technique used the partial least square (PLS) approach. PLS is a component-based or variant-based structural equation model (SEM). The results of the analysis show that business risk, company size, and asset structure have a significant effect on profitability. Business risk, company size and asset structure have a significant effect on capital structure. Profitability has no significant effect on capital structure. Profitability cannot mediate the effect of business risk, company size, and asset structure on capital structure.
\end{abstract}

Keywords: Business Risk, Company Size, Asset Structure, Capital Structure, Profitability

\section{INTRODUCTION}

The capital structure is a permanent expenditure which also reflects the balance between long-term debt and own capital (Riyanto, 2015). Determining the capital structure for a company is one form of important financial decisions, because this decision can affect the achievement of the company's financial management objectives. The main objective of capital structure management is to create a mix or combination of permanent sources of spending in such a way as to maximize the company's stock price.

The optimal capital structure can be interpreted as a capital structure that can minimize the overall cost of capital or the average cost of capital so that it will maximize the value of the company (Harjito and Martono, 2014). Companies need to pay attention to determining the capital structure, especially the composition of long-term sources of spending. Determining the right composition of company spending will form an optimal capital structure (Wangsawinangun, 2014).

Every company requires that under no circumstances have debt greater than the amount of capital, or in other words the debt ratio is smaller than $50 \%$ so that the guaranteed capital is not greater than the capital that is guaranteed (Riyanto, 2015). If the company relies on debt as its main source of capital, the burden that must be borne will be large. This will increase financial risk, where the risk is when the company cannot pay the interest expense and debt installments. The capital structure that can minimize the cost of using the 
Robby Rahadi Putra et.al. Effect of business risk, company size, and asset structure on capital structure with profitability as an intervening variable (case study on manufacturing companies on the Indonesia stock exchange).

average capital is the optimal capital structure (Riyanto, 2015).

According to Brigham and Houston (2014) the factors that generally affect the capital structure are sales stability, asset structure, operating leverage, growth rate, profitability, taxes, management attitudes, market conditions, market conditions, internal company conditions, financial flexibility. Meanwhile, according to Riyanto (2015) the factors that influence the capital structure are the interest rate, the stability of the earning level, the composition of assets, the level of risk, the amount of capital required. In this study, the independent variables of several factors that influence the capital structure, namely business risk, company size, and asset structure, and profitability factors as intervening variables are selected.

According to Gitman and Zutter (2015) business risk is a key position in the capital structure and the amount represents the number of expense components attached to the company's operational activities even without using debt financing. High business risk will reduce the company's ability to earn profits because there are costs that must be incurred to anticipate these risks. Furthermore, if business risk increases, the capital structure will decrease because creditors are hesitant to provide loans to companies with high business risk, it will be difficult to repay loans. This supports the research of Sari et al. (2019) which proves that business risk has a negative effect on capital structure, but contradicts the research of Ria and Lestari (2015) and Meilyani et al. (2020) proves that business risk has a positive effect on capital structure.

Riyanto (2015) explains that company size is the size of the company seen from the amount of equity value, company value, or the total asset value of a company. If the size of the company increases, profitability will also increase because the size of the company is able to reduce the production costs incurred so that it is able to produce more goods so as to increase profit margins. The increasing size of the company will increase the capital structure because the greater the total assets of the company, it will allow the company to obtain loans from creditors.

Asset structure is the determination of how much allocation for each component of assets, both in current assets and fixed assets (Syamsuddin, 2011). Asset structure describes some of the total assets that can be used as collateral. If the asset structure is high, profitability will decrease because companies with high fixed assets tend to require large capital costs. Companies with high asset growth rates will use debt in their capital structure more than companies with low asset growth rates. Manufacturing companies generally use the largest capital they have to purchase fixed assets which will prioritize the fulfillment of capital in the form of internal funds while external funds are considered complementary.

Profitability shows the company's ability to generate profits during one accounting period. In general, profitability can be seen from the amount of profit for the year, therefore from short-term debt, the pecking order theory explains that companies prefer internal funding. Companies with high levels of profitability certainly have more internal funds than companies with low levels of profitability. Companies with high returns tend to have relatively little investment or use debt (Brigham and Houston, 2014). Profitability is a factor to consider in determining the company's capital structure because companies that have a high level of profitability tend to use less debt because high retained earnings are sufficient to finance most funding needs.

The company Astra International, Tbk, has a debt to equity ratio (DER) value greater than $50 \%$. Therefore, it is stated that during 2015-2019 the company was in a non-optimal capital structure position. In contrast to Delta Jakarta, Tbk and Eka Dharma International, Tbk which have DER less than 50\%, during 2015-2019 these two companies are in an optimal position of capital structure. Furthermore, the value of 
Robby Rahadi Putra et.al. Effect of business risk, company size, and asset structure on capital structure with profitability as an intervening variable (case study on manufacturing companies on the Indonesia stock exchange).

the basic earning power ratio (BEPR) at Astra International, Tbk and Eka Dharma International, Tbk is smaller than the average BEPR for manufacturing companies (average 0.1156 or $11.56 \%$ ), it is stated that during 2015 -2019 These two companies are below the average percentage of operating income per total company assets. The asset structure is stated that the company Delta International, Tbk during 2015-2019 is smaller than $50 \%$, so this company has a low ability to be able to guarantee the debt on its asset collateral.

The purpose of this study was to determine and analyze the effect of business risk, company size, and asset structure on capital structure with profitability as an intervening variable (case study on Manufacturing Companies on the Indonesia Stock Exchange).

\section{RESEARCH METHODS}

The populations in this study are all Manufacturing Companies listed on the Indonesia Stock Exchange for the 20152019 period. Based on the purposive sampling method, 71 companies were obtained as samples. The data analysis technique used the partial least square (PLS) approach. PLS is a component-based or variant-based structural equation model (SEM).

The research used in this study is an associative quantitative research type. According to Sugiyono (2014:8) quantitative research is a research method based on the philosophy of positivism, used to examine certain populations or samples, data collection using research instruments, quantitative or statistical data analysis with the aim of testing predetermined hypotheses.

The populations in this study are all Manufacturing Companies listed on the Indonesia Stock Exchange for the 20152019 period. According to Pandiangan et al. (2018) in Sugiyono, purposive sampling is the selection of samples based on certain characteristics that are considered to have relevance to the characteristics of the population that have been known previously. Based on the purposive sampling method, 71 companies were obtained as samples.

Data collection techniques in this study used secondary data and library research. Library research is a form of research that uses library facilities by examining theoretical discussions from various books, articles, and scientific works related to writing (Pandiangan, 2018).

The data analysis technique used the partial least square (PLS) approach. PLS is a component-based or variant-based structural equation model (SEM).

\section{RESULT \\ Descriptive Statistics}

Descriptive statistics provide an overview of the research object that is used as the research sample. By providing an explanation of descriptive statistics, it is hoped that it can provide an initial picture of the problem being studied.

Table 1. Descriptive Statistics

\begin{tabular}{|l|c|c|c|}
\hline Variable & Mean & Minimum & Maximum \\
\hline Business Risk $\left(\mathrm{X}_{1}\right)$ & 0.11 & 0.00 & 0.71 \\
\hline Company Size $\left(\mathrm{X}_{2}\right)$ & 23.82 & 12.41 & 0.81 \\
\hline Asset Structure $\left(\mathrm{X}_{3}\right)$ & 0.44 & 0.00 & 30.64 \\
\hline Capital Structure $\left(\mathrm{Y}_{2}\right)$ & 0.89 & 0.08 & 13.98 \\
\hline Profitability $\left(\mathrm{Y}_{1}\right)$ & 0.08 & 0.00 & 0.53 \\
\hline
\end{tabular}

The results of descriptive statistical tests, it can be seen that the data used in this study is very varied. The lowest value of the capital structure of 0.08 indicates that manufacturing companies listed on the BEI for the 2015-2019 period have the lowest debt to equity ratio, namely PT Industri Jamu and Farmasi Sido Muncul, Tbk in 2015 and 2016, the low debt to equity ratio in the 2015-2019 period. This shows that PT Industri Jamu dan Farmasi Sido Muncul, Tbk was able to manage debt repayments better than in 2017 where the DER value rose slightly to 0.09 . The highest value of the capital structure of 13.98 indicates that the manufacturing company listed on the Indonesia Stock Exchange for the 20152019 period has the highest debt to equity 
Robby Rahadi Putra et.al. Effect of business risk, company size, and asset structure on capital structure with profitability as an intervening variable (case study on manufacturing companies on the Indonesia stock exchange).

ratio, namely PT Merck Sharp Dohme Pharma, Tbk in 2015. The high debt to equity in that period shows PT Merck Sharp Dohme Pharma, Tbk does not manage debt repayments to related parties, especially from related parties, which amounted to 1.28 trillion rupiah with a total capital of 100.87 billion rupiah.

The lowest value of profitability of 0.00 indicates that manufacturing companies listed on the Indonesia Stock Exchange for the 2015-2019 period have the lowest return on assets, one of which is PT Nusantara Inti Copora, Tbk in 2015-2019. The low return on assets of the company indicates that the company is not able to maximize its asset turnover in running the company's operations so that the company's rate of return is low. The highest value of profitability of 0.53 indicates that manufacturing companies listed on the Indonesia Stock Exchange for the 20152019 period have the highest return on assets, namely PT Multi Bintang Indonesia, Tbk in 2017. The high return on assets in that period shows PT Multi Bintang Indonesia, Tbk in 2015 was able to increase the rate of return on assets by $10 \%$ from 2014.

The lowest value of business risk is 0.00 , indicating that manufacturing companies listed on the Indonesia Stock Exchange for the 2015-2019 period have the lowest basic earning power ratio, one of which is PT Buana Artha Anugerah, Tbk in 2015-2019. The low basic earning power ratio indicates that the company's high risk for 5 consecutive years has resulted in the company having to cover this risk by spending funds so that profits are getting smaller. The highest value of business risk of 0.71 indicates that manufacturing companies listed on the IDX for the 20152019 period have the highest basic earning power ratio.

PT Multi Bintang Indonesia, Tbk in 2017. The high basic earning power ratio shows that PT Multi Bintang Indonesia has a lower risk than the average risk experienced by similar companies of 0.109 so that the company is able to increase profits because it avoids risk financing.

The lowest value of company size is 12.41, indicating that manufacturing companies listed on the Indonesia Stock Exchange for the 2015-2019 period have the lowest natural logarithm value of total assets.

PT Astra International, Tbk in 2015. The highest value of company size is 30.64 indicating that the manufacturing company listed on the Indonesia Stock Exchange for the 2015-2019 period has the natural logarithm value of the highest total assets is PT Kalbe Farma, Tbk in 2019. The value is PT Astra International, Tbk. This describes the size of the asset value of a company because the assets themselves are used to generate company income. The high value of the company's assets can increase the scale of the company's operations so as to increase the income.

The lowest value of the asset structure is 0.00 , indicating that the manufacturing company listed on the BEI for the 2015-2019 period has the lowest asset structure is PT Buana Artha Anugerah, Tbk in 2019. The low ratio of asset structure at PT Buana Artha Anugerah, Tbk shows the small the value of fixed assets owned by the company so that in relation to the company's capital structure it will be difficult to provide guarantees to lenders because the fixed assets owned are $0.12 \%$ of the total assets. The highest value of the asset structure is 0.81 indicating that the manufacturing company listed on the BEI for the 2015-2019 period has the highest asset structure is PT Semen Baturaja (Persero), Tbk in 2016. The high ratio of asset structure at PT Semen Baturaja (Persero), Tbk shows that $80.81 \%$ of fixed assets owned can be used as collateral to lenders if the company is unable to pay off its debts or goes bankrupt so that it cannot pay it off.

\section{Hypothesis Test Results}

Based on the data processing that has been done, the results can be used to 
Robby Rahadi Putra et.al. Effect of business risk, company size, and asset structure on capital structure with profitability as an intervening variable (case study on manufacturing companies on the Indonesia stock exchange).

answer the hypothesis in this study. Hypothesis testing in this study was conducted by looking at the $\mathrm{t}$-statistic and $\mathrm{p}$ value. The independent variable is declared to have a significant effect on the dependent variable if the t-statistic $>1.96$ and $p$ value $<0.05$. The following are the results of data processing in this study using SmartPLS version 3.0:

Table 2. t-Statistic and p-Value

\begin{tabular}{|c|l|c|c|c|}
\hline Hypothesis & Effect & t-Statistic & p-Value & Coefficient \\
\hline 1 & Business Risk->Profitability & 17.820 & 0.000 & 0.735 \\
\hline 2 & Company Size->Profitability & 4.107 & 0.000 & -0.143 \\
\hline 3 & Asset Structure->Profitability & 2.369 & 0.018 & -0.100 \\
\hline 4 & Business Risk->Capital Structure & 4.031 & 0.000 & -0.367 \\
\hline 5 & Company Size->Capital Structure & 3.456 & 0.001 & -0.130 \\
\hline 6 & Asset Structure->Capital Structure & 2.698 & 0.007 & -0.163 \\
\hline 7 & Profitabilitas->Capital Structure & 1.483 & 0.139 & -0.179 \\
\hline
\end{tabular}

Table 3. Total Indirect Effect

\begin{tabular}{|l|c|c|c|}
\hline & t-statistic & p-Value & Result \\
\hline Business Risk->Profitability->Capital Structure & 1.43 & 0.15 & Not Mediating \\
\hline Company Size->Profitability->Capital Structure & 1.58 & 0.12 & Not Mediating \\
\hline Asset Structure-> Profitability-> Capital Structure & 1.46 & 0.15 & Not Mediating \\
\hline
\end{tabular}

Based on Table 2 and 3, the results of the analysis show that business risk, company size, and asset structure have a significant effect on profitability. Business risk, company size and asset structure have a significant effect on capital structure. Profitability has no significant effect on capital structure. Profitability cannot mediate the effect of business risk, company size, and asset structure on capital structure.

\section{CONCLUSION AND SUGGESTION}

The results of the analysis show that business risk, company size, and asset structure have a significant effect on profitability. Business risk, company size and asset structure have a significant effect on capital structure. Profitability has no significant effect on capital structure. Profitability cannot mediate the effect of business risk, company size, and asset structure on capital structure.

Based on the conclusions obtained, the authors would like to provide suggestions for interested parties, namely as follows:

1. It is hoped that the results of this study can be used as comparison materials and references for further research so that they can continue research with capital structure using other measuring tools that have not been studied such as market value assets to book value assets ratio, current ratio, capital expenditure to book value assets so that can be useful for interested parties.

2. For further researchers when using the company size variable to equate the total unit of assets because the published financial statements have different units.

\section{Acknowledgement: None}

\section{Conflict of Interest: None}

\section{Source of Funding: None}

\section{REFERENCES}

1. Brigham, E. F., \& Houston, J. F. (2014). Dasar-dasar Manajemen Keuangan. Edisi 11, Buku 1. Jakarta: Salemba Empat.

2. Gitman, L. J., \& Zutter, C. J. (2015). Principles of Managerial Finance. 14th Edition. USA: Pearson Education.

3. Harjito, D. A., \& Martono, S. U. (2014). Manajemen Keuangan. Edisi 2. Semarang: Ekonisia.

4. Meilyani, I. G. A. A., Suci, N. M., \& Cipta, W. (2019). Pengaruh Risiko Bisnis, Ukuran Perusahaan dan Pertumbuhan Penjualan Terhadap Struktur Modal pada Perusahaan Properti dan Real Estate Yang Terdaftar di Bursa Efek Indonesia. Prospek: Jurnal Manajemen dan Bisnis, 1(2), 15-24. 
Robby Rahadi Putra et.al. Effect of business risk, company size, and asset structure on capital structure with profitability as an intervening variable (case study on manufacturing companies on the Indonesia stock exchange).

5. Pandiangan, Saut Maruli Tua. (2018). Analisis Faktor-faktor yang Mempengaruhi Penawaran Tenaga Kerja Lanjut Usia di Kota Medan. Tesis. Medan: Fakultas Ekonomi dan Bisnis, Program Studi Ilmu Ekonomi, Universitas Sumatera Utara. http://repositori.usu.ac.id/bitstream/handle/1 23456789/10033/167018013.pdf?sequence $=$ $1 \&$ isAllowed=y.

6. Pandiangan, Saut Maruli Tua, Rujiman, Rahmanta, Tanjung, Indra I., Darus, Muhammad Dhio, \& Ismawan, Agus. (2018). An Analysis on the Factors which Influence Offering the Elderly as Workers in Medan. IOSR Journal of Humanities and Social Science (IOSR-JHSS), 23(10), 76-79. DOI: $\quad 10.9790 / 0837-2310087679$. http://www.iosrjournals.org/iosrjhss/papers/Vol.\%2023\%20Issue10/Version -8/K2310087679.pdf.

7. Ria, Y., \& Lestari, P. (2015). Pengaruh Risiko Bisnis, Ukuran Perusahaan Dan Pertumbuhan Penjualan Terhadap Struktur Modal. E-Jurnal Manajemen Universitas Udayana, 4(5), 1238-1251.

8. Riyanto, B. (2015). Dasar-dasar Pembelanjaan Perusahaan. Edisi Keempat. Yogyakarta: BPFE.
9. Sari, S. Y., Ramadhani, D., \& Yulia, Y. (2019). Pengaruh Risiko Bisnis, Struktur Aktiva, Ukuran Perusahaan, Dan Pertumbuhan Penjualan Terhadap Struktur Modal. Jurnal Ekobistek, 8(2), 10-19.

10. Sugiyono. (2014). Metode Penelitian Pendidikan Pendekatan Kuantitatif, Kualitatif dan R\&D. Bandung: Alfabeta.

11. Syamsuddin, L. (2011). Manajemen Keuangan Perusahaan: Konsep Aplikasi dalam: Perencanaan, Pengawasan, dan Pengembaian Keputusan. Jakarta: PT Raja Grafindo.

12. Wangsawinangun, R. (2014). Penetapan Struktur Modal yang Optimal dalam Upaya Meningkatkan Nilai Perusahaan (Studi Pada PT. Astra International, Tbk dan Anak Perusahaan Tahun 2008-2012). Jurnal Administrasi Bisnis, 9(2), 1-8.

How to cite this article: Putra RR, Sari M, Astuty W. Effect of business risk, company size, and asset structure on capital structure with profitability as an intervening variable (case study on manufacturing companies on the Indonesia stock exchange). International Journal of Research and Review. 2021; 8(8): 284-289. DOI: https://doi.org/10.52403/ijrr. 20210839 